\title{
Protected Area Systems in South American Countries
}

\author{
Geraldo Majela Moraes Salvio' ${ }^{10}$, Carolina Ribeiro Gomes ${ }^{1}$ (D) \\ ${ }^{1}$ Instituto Federal de Educacão, Ciência e Tecnologia do Sudeste de Minas Gerais - IF Sudeste MG, Campus Barbacena, \\ Barbacena/MG, Brasil
}

\begin{abstract}
Protected Areas (PA) represent an important biodiversity conservation strategy, but these areas are threatened by increasing human pressure and inefficient management. Thus, the objective was to analyze the management of PA in South America, a continent with particular characteristics in relation to the political and socioeconomic complexity that reflect the way each country manages its PA. The results showed that, although there is progress in establishing PAs, there is only effective protection when they have adequate size and management, and Protected Area Systems (PAS) are established. It was possible to observe the importance of the PAS, since, PA managed outside it have comprehensive norms, without defined criteria, with several organs operating without connection. For PA management, uniform and standardized actions are fundamental in order to allow a global network for biodiversity protection.
\end{abstract}

Keywords: NPAS, national park, conservation of natural areas. 


\section{INTRODUCTION}

Protected Areas (PA) represent an important conservation strategy, in situ, of biodiversity, contributing to the maintenance of natural environments, as well as ensuring the conservation of rare and endangered species (Pimm et al., 2001; Joppa et al., 2008; Butchart et al., 2010; Scharlemann et al., 2010). However, there are still gaps in the establishment of biodiversity protection goals (Bruner et al., 2001; Rodrigues et al., 2004a), which hampers the effectiveness of the global PA network due to the lack of reliable ecological information, functional connectivity between protected sites and the need for greater coherence between conservation policy and other policies (Davis et al., 2014).

After the Convention on Biological Diversity progress has been made towards the protection of biomes and eco-regions. Global legal protection has increased by $12.9 \%$ since then, although only $5.8 \%$ is full protection (Jenkins \& Joppa, 2009; Tuvi et al., 2011). It is estimated that the number of Protected Areas in the world has doubled in the last ten years, reaching approximately 200,000 in 2016 (Lushaj et al., 2016). About $13 \%$ of biomes and eco-regions still do not have PA, which expanded by an average of only $0.13 \%$ per year, especially Brazil, mainly in the Amazon (Jenkins \& Joppa, 2009).

Although there is an increase in the creation of PA in Brazil and in the world, countries have not yet reached significant rates to reduce biodiversity loss. Among the 20 Aichi Targets for 2020, as a global guideline on biodiversity, we highlight the Goal 11, that deal with protected areas, aiming at their effectiveness, ecological representativeness, governance and connectivity among them (Prates \& Irving, 2015), covering until 2020 17\% of terrestrial and inland (continental) waters and 10\% of marine and coastal areas, managed effectively and equitably, functioning as connected and integrated systems (Juffe-Bignoli et al., 2014).

Globalization processes have substantially leveraged the creation of protected areas and nature conservation. Political, social, cultural and environmental connections have led to the involvement of various organizations in the management of PA worldwide (Zimmerer et al., 2004; Martin et al., 2016). These actions have been increasingly outlined by global institutions, including the United Nations and the International Union for
Conservation of Nature and Natural Resources (IUCN), guiding the establishment of Protected Area Systems, expanding their recognition, favoring the allocation of resources and ensuring a management environmentally and legally balanced (Watson et al., 2014).

Even if protected areas have conservation benefits compared to unprotected areas, it is clear that the effectiveness of any PA requires support, so that they do not become just "Paper Parks", those created but not deployed. Increasing human pressure around protected areas continues to threaten the planet's resources (Martinuzzi et al., 2015), in this way, the creation of a global system of protected areas makes conservation viable and internationally representative (Chape et al., 2005). In order to achieve this goal, it is essential that countries manage their PA within coordinated and legally instituted systems.

The introduction of a Protected Areas System (PAS) implies greater representation in favor of the ecological and biological diversity of the territory, together with duly defined criteria, uniformity of norms, management categories, management rules and economic resources compatible with the need of each area. (Dourojeanni, 2010). Systematic conservation planning can be seen as a process for establishing tasks and targets for priority decisions (Margules \& Pressey, 2000). An administrative authority brings rules for all units of the System (Dourojeanni, 2010), which should be managed, identifying forces and threats to ensure effective management, and if necessary, shaping to international standards (Fouda et al., 2006).

These patterns were reflected in actions for the protection of biodiversity, being accelerated over the years particularly through the efforts of the IUCN (Brooks et al., 2004). For this reason and due to the diversity of areas and forms of management, IUCN (Dudley, 2008) developed the System of Categories of Management of Protected Areas to guide the definition, classification and organization of these areas by defining different categories with different conservation objectives (Table 1).

The categories I to IV are of full protection and are more restrictive (Jenkins \& Joppa, 2009), while categories $\mathrm{V}$ and VI are subject to management and direct use of resources (Joppa et al., 2008). The categories created by the IUCN are recognized by international organizations and national governments, which use 
Table 1. System of Categories of Management of Protected Areas proposed by IUCN and their respective conservation objectives.

\begin{tabular}{|c|c|}
\hline Category & Conservation objectives \\
\hline $\begin{array}{l}\text { I-A } \\
\text { Strict natural reserve }\end{array}$ & $\begin{array}{l}\text { Preserve, at a regional, national and global level, ecosystems, species and } \\
\text { geological heritage. Being sensitive to human presence. }\end{array}$ \\
\hline $\begin{array}{l}\text { I-B } \\
\text { Wildlife Area }\end{array}$ & $\begin{array}{l}\text { Protect the integrity of natural areas that have not been modified by human } \\
\text { activities or few modifications, maintaining the original character, with the } \\
\text { absence or with little human presence, preserving the natural condition of the } \\
\text { environment. }\end{array}$ \\
\hline $\begin{array}{l}\text { II } \\
\text { National park }\end{array}$ & $\begin{array}{l}\text { Protect natural biodiversity, ecosystems, ecological structures and environmental } \\
\text { processes. The site should be used to promote environmental education, } \\
\text { recreation and research. All activities should focus on the conservation of nature. }\end{array}$ \\
\hline $\begin{array}{l}\text { III } \\
\text { Natural monument }\end{array}$ & $\begin{array}{l}\text { Protect striking specific features associated with biodiversity } \\
\text { and the habits associated with this biodiversity. }\end{array}$ \\
\hline $\begin{array}{l}\text { IV } \\
\text { Area of management of species and } \\
\text { habitats }\end{array}$ & Maintain, preserve and restore species and habitats. \\
\hline $\begin{array}{l}\mathrm{V} \\
\text { Land and marine protected } \\
\text { landscapes }\end{array}$ & $\begin{array}{l}\text { Protect and maintain important land and marine landscapes, allowing the } \\
\text { presence of humans and activities and traditional management practices. }\end{array}$ \\
\hline $\begin{array}{l}\text { VI } \\
\text { Protected area for the sustainable } \\
\text { use of natural resources }\end{array}$ & $\begin{array}{l}\text { Protect natural ecosystems and the uses of natural resources provided in a } \\
\text { sustainable manner generating mutual benefits. }\end{array}$ \\
\hline
\end{tabular}

Source: Dudley, 2008.

them as a reference to classify their management systems (Dudley, 2008).

There is great gap to be filled in PA management in the world. Its importance as a strategy to contain biodiversity loss is already recognized, but the protection of ecosystems must be accompanied by the training of qualified professionals (Pimm et al., 2001; Irving \& Matos, 2006; Santos \& Krawiec, 2011), as well as being inserted in policy decisions and having adequate funding (Bruner et al., 2001).

Considering the different categories and denominations that vary between countries and their legislations (Pimm et al., 2001), the objective was to identify and analyze the management of protected areas in South America, considering the importance of the Protected Areas System, the level of protection on the continent, the average size of areas and the adaptation of countries to the IUCN International Category System.

\section{MATERIAL AND METHODS}

Data on the distribution of protected areas were obtained from IUCN and the World Database on Protected Areas (WDPA). In Brazil, the information was acquired through the Federal Audit Court, the National System of Nature Conservation Units and the
National Register of Conservation Units. In the other countries, environmental legislations and information about the PAS were researched. Relevant articles and books were also used.

The legislations regarding PAS investigated were: (Argentina, 2003) - Statutory Framework of the Federal System of Protected Areas (Marco Estatutário del Sistema Federal de Áreas Protegidas); (Bolívia, 1992) - Law $\mathrm{n}^{\circ} 1.333$ - Law of the Environment (Ley del Medio Ambiente); (Brasil, 2000) - Law nº 9.985 - National System of Nature Conservation Units (Sistema Nacional de Unidades de Conservação da Natureza); (Chile, 1984) - Law no 18.362 - National System of Protected Wild Areas of the State (Sistema Nacional de Áreas Silvestres Protegidas del Estado); (Colombia, 2010) Decree $n^{\circ} 2.372$ - National System of Protected Areas (Sistema Nacional de Áreas Protegidas); (Ecuador, 1976) - Preliminary Strategy for the Conservation of Outstanding Wildland Areas of Ecuador (Estrategia Preliminar para la Conservación de Áreas Silvestres Sobresalientes del Ecuador); (Guyana, 2011) - Act n ${ }^{\circ} 14$; (Paraguay, 1994) - Law no 352/94; (Peru, 1997) - Law $\mathrm{n}^{\circ}$ 26.834; (Venezuela, 1983) - Law $\mathrm{n}^{\circ} 3.238$; (Uruguay, 2000) - Law n ${ }^{\circ} 17.234$.

The types of management, forms of management and creation of protected areas were analyzed, analyzing 
the date of creation, quantity and total area, types of management categories, percentage protected in relation to the territorial extension of the country and the average size of PA in each country.

The countries adaptation to the IUCN Protected Areas Management System was also verified to guide the definition, classification and organization of the national system of the South American countries. It should be noted that the Protected Areas described and instituted by the National Systems of Protected Areas or the legislation corresponding to them in each country were considered.

\section{RESULTS AND DISCUSSION}

Of the South American countries, 11 have Protected Area Systems with different nomenclatures and quantities of management categories (Figure 1). Map of countries with NPAS.

Venezuela has the largest number of categories in South America, 26. On the other hand, Chile has the smallest amount, with 4 management categories (Table 2). In spite of maintaining international agreements,
Chile has a high rate of species losses (Gay, 2001), which can be attributed to insufficient strategies and disagreement among public services when applying them (Jorquera-Jaramillo et al., 2012).

French Guyana has 29 autonomous PA distributed in 11 management categories, and administered by different government agencies. Suriname has 3 management categories with 16 PA, managed by the Forest Service through the Nature Conservation Division, assisted by the Suriname Nature Conservation Foundation (STINASU).

Manage PA outside a System generates comprehensive criterion with different organs acting without connection. Centralizing the management of PA in a system allows homogenous norms, equal categories with similar objectives, connectivity between areas and rules harmonized with the management needs of each location (Dourojeanni, 2010).

The Peruvian system stands out because it presents a provisional category, (Reserved Area (Zona Reservada), where complementary studies are carried out to determine and qualify which category will be most appropriate to

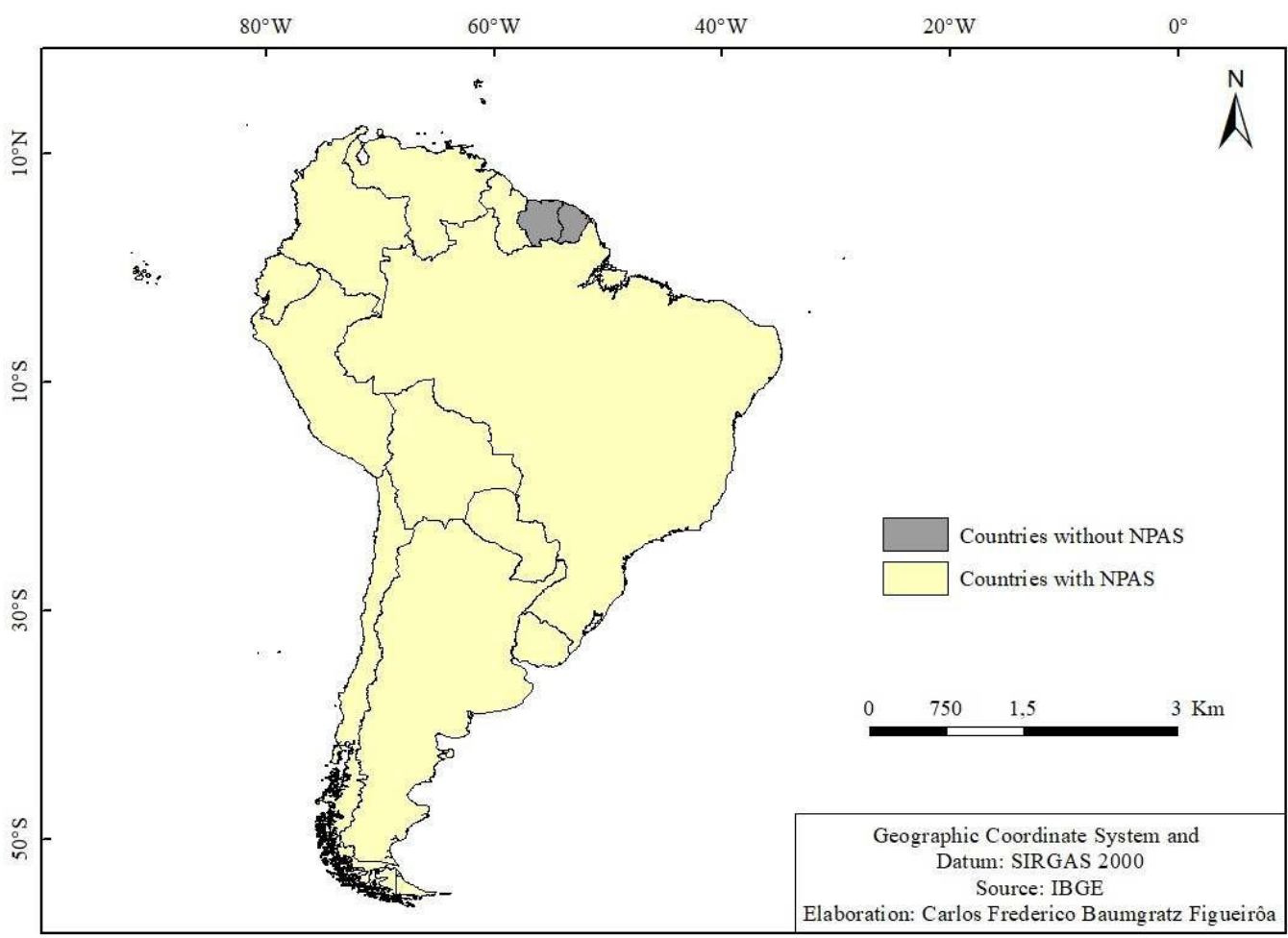

Figure 1. Map of South America highlighting in yellow the countries that have National Protected Areas System (NPAS). In gray: countries without NPAS. 
Table 2. South American countries with National Systems of Protected Areas, number of management categories and the acronym of the system).

\begin{tabular}{|c|c|c|c|}
\hline Country & System (original name in parentheses) & Categories & $\begin{array}{c}\text { Acronym } \\
\text { (in the original language) }\end{array}$ \\
\hline Argentina & $\begin{array}{l}\text { Federal System of Protected Areas (Sistema Federal de } \\
\text { Áreas Protegidas) }\end{array}$ & 6 & SIFAP \\
\hline Bolivia & $\begin{array}{l}\text { National Protected Areas System (Sistema Nacional de } \\
\text { Áreas Protegidas) }\end{array}$ & 6 & SNAP \\
\hline Brazil & $\begin{array}{l}\text { National System of Conservation Units of Nature (Sistema } \\
\text { Nacional de Unidades de Conservação da Natureza) }\end{array}$ & 12 & SNUC \\
\hline Chile & $\begin{array}{l}\text { National Protected Wild Areas System of the State (Sistema } \\
\text { Nacional de Áreas Silvestres Protegidas del Estado) }\end{array}$ & 4 & SNASPE \\
\hline Colombia & $\begin{array}{l}\text { National Protected Areas System (Sistema Nacional de } \\
\text { Áreas Protegidas) }\end{array}$ & 11 & SINAP \\
\hline Ecuador & $\begin{array}{l}\text { National Protected Areas System (Sistema Nacional de } \\
\text { Áreas Protegidas) }\end{array}$ & 8 & SNAP \\
\hline Guyana & National Protected Areas System & 7 & NPAS \\
\hline Paraguay & $\begin{array}{l}\text { National Wild Areas } \\
\text { Protected System (Sistema Nacional de Áreas Silvestres } \\
\text { Protegidas }\end{array}$ & 10 & SINASIP \\
\hline Peru & $\begin{array}{l}\text { National Natural Areas Protected by the State System } \\
\text { (Sistema Nacional de Áreas Naturales Protegidas por el } \\
\text { Estado) }\end{array}$ & 11 & SINANPE \\
\hline Uruguay & $\begin{array}{l}\text { National Protected Areas System (Sistema Nacional de } \\
\text { Áreas Protegidas) }\end{array}$ & 6 & SNAP \\
\hline Venezuela & $\begin{array}{l}\text { Areas Under Special Administration Regime (Áreas Bajo } \\
\text { Regime de Administración Especial) }\end{array}$ & 26 & ABRAE \\
\hline
\end{tabular}

Source: Argentina (2003); Bolívia (1992); Brasil (2000); Chile (1984); Colômbia (2010); Ecuador (1976); Guyana (2011); Paraguai (1994); Peru (1997); Uruguai (2000); Venezuela (1983).

the area. National Park is the only category common to all South American systems, being the most frequent category of management in all the countries of the world (Meneguel \& Etchebehere, 2011).

Venezuela defines its PA as "areas under special administration regime". Brazil, however, is the only country that uses the term "Conservation Unit" to refer to the protected areas in the SNUC. In view of the diversity of systems, with different categories, objectives and nomenclatures, very particular characteristics were observed in relation to the culture, economy and history of each country. The existence of different nomenclatures and management objectives is not necessarily negative, however, it is a greater challenge in the search for a standard for the administration of these areas (Dourojeanni \& Pádua, 2001).

Despite the differences, mainly in relation to the number of categories found, most of the South American countries have a specific law, through Protected Area Systems, unifying the rules for the administration of priority areas for conservation. However, a large number of categories, even within a PAS, can disharmonize the system as a whole, causing confusion in goals and definitions (Dourojeanni, 2010). In Venezuela, although the PAS includes 26 management categories, only 7 of them are recognized by the IUCN.

However, there are several strategies to promote sustainable management, it is still an urgent need to prioritize conservation actions, which face the developmental tendency to become effective (Margules \& Pressey, 2000; Bruner et al., 2001; Pimm et al., 2001; Rodrigues et al., 2004b; Chape et al., 2005). Some systems are inefficient and rarely can systematically include all species that need to be protected (Eken et al., 2004).

Effectiveness in PA management depends on communication between countries in a global network (Don Carlos et al., 2013). If there is an exchange of ideas between groups who work with conservation, and which face the daily challenges of dealing with threats to biodiversity, the results will be promising (Margules \& Pressey, 2000). It is necessary, therefore, to change the implementation of measures and decisions 
in the management of PA so that, although they are consistent with the reality of each place, they become more homogenous and standardized facilitating the interlocution between the different countries.

South America had, in 1985, 3.89\% of protected area; in 1997, this coverage expanded to $10.26 \%$, corresponding to $1,837,825 \mathrm{~km}^{2}$ (IUCN, 1985; IUCN, 1998; Zimmerer et al., 2004). In 2005, South America had $12.4 \%$ of its protected territory (Chape et al., 2005). Currently, the 13 countries, which correspond to the total $17,840,000 \mathrm{~km}^{2}$ of territorial extension, protect more than $3,000,000 \mathrm{~km}^{2}$, that is, about $16 \%$ of South America. This value is close to Aichi's goal of protecting $17 \%$ of the territory by 2020 (Juffe-Bignoli et al., 2014; Prates \& Irving, 2015). This advance coincided with the creation of PAS, which became common from the late 1990s and early 2000s (Table 3).

In the early 2000s Brazil protected about $15 \%$ of its territory (Chape et al., 2005) and in 2016 this value reached $17.2 \%$. Of the $16 \%$ protection in South America, about $8 \%$ is Brazilian territory. Although the effective Brazilian protected area is larger than other countries, smaller countries with high protection percentages, such as French Guyana (57\%) and Venezuela (36.3\%) show a clear conservationist tendency by giving up their territory of extensive agriculture and industrial development. Even tough, it is noted that protection is effective when there are areas with adequate size and management (Schodelbauerova et al., 2009;
Armsworth et al., 2011). The Amazon has large forest cover and incorporates large protected areas (Joppa et al., 2008), but in other South American biomes the areas are small and it was found that the average size is not related to the territorial dimension of the country. Furthermore, in South America, 52\% of Protected Areas have an average implementation and effectiveness index and only 19\% are considered to be highly effective (Table 4).

Conservation efforts should be directed to maximize the size of areas in each country (Schodelbauerova et al., 2009). Small areas, mostly, do not fulfill the functions for which they are created, not guaranteeing the conservation of local biodiversity, as in Colombia and Uruguay. Relatively minor areas undermine biodiversity and ecosystem integrity, leading to declining species populations due to external threats (Kharouba \& Kerr, 2010; Humbley \& Canney, 2013). While, larger areas without good implementation and management effectiveness indices also do not fulfill their functions.

Although Brazil is the country with the highest number of protected areas, countries like Bolivia and Peru, with areas twice Brazil's average size, are able to protect $20.2 \%$ and $18.5 \%$ of their territories, respectively, percentages larger than Brazil.

Managing organs should minimize the negative effects of small areas by investing in ecological corridors, which, because of their design, ensure the protection of endangered species. Connectivity through the corridors

Table 3. Year of creation of Protected Area Systems, territorial extension and protected area of the South American countries.

\begin{tabular}{|c|c|c|c|}
\hline Country & Year of PAS creation & $\begin{array}{l}\text { Territorial Extension } \\
\left(\mathbf{k m}^{2}\right)\end{array}$ & Protected Area (\%) \\
\hline Argentina & 2003 & 2.791 .810 & 7.7 \\
\hline Bolivia & 1992 & 1.098 .581 & 20.2 \\
\hline Brazil & 2000 & 8.515 .767 & 17.2 \\
\hline Chile & 1984 & 756.950 & 19.6 \\
\hline Colombia & 2010 & 1.141 .748 & 12.4 \\
\hline Ecuador & 1976 & 256.370 & 19.6 \\
\hline Guyana & 2011 & 214.999 & 4.8 \\
\hline French Guyana & - & 83.992 & 57 \\
\hline Paraguay & 1994 & 406.752 & 20.5 \\
\hline Peru & 1999 & 1.294 .364 & 18.5 \\
\hline Suriname & - & 163.821 & 11.9 \\
\hline Uruguay & 2000 & 176.215 & 1.5 \\
\hline Venezuela & 1983 & 1.075 .987 & 36.3 \\
\hline
\end{tabular}

Source: Argentina (2003); Bolívia (1992); Brazil (2000); Chile (1984); Colombia (2010); Ecuador (1976); Guyana (2011);

Dudley (2008); Paraguay (1994); Peru (1997); TCU (2015); Uruguay (2000); Venezuela (1983). 
is essential for the functioning of ecological services and is crucial for the maintenance of biodiversity (Zhu et al., 2010; Willis et al., 2012). Currently, there are few coordinated networks of nature conservation areas aimed at improving connectivity at the continental level (Orlikowska et al., 2016). The connectivity between the areas is fundamental, avoiding the interruption of the gene flow between the species (Jorquera-Jaramillo et al., 2012; Don Carlos et al., 2013; Prates \& Irving, 2015).

The definitions of IUCN categories imply a restriction gradient, so that category Ia protected areas are more natural, with less human interference (Leroux et al., 2010). Countries are expected to prioritize stricter areas, as these have stricter conservation objectives and less human influence. However, Chape et al. (2005) showed that categories Ia and Ib are less common. In North America the most common category is II, in South Asia IV, in Europe V and in North Africa the predominant category is VI (Meneguel \& Etchebehere, 2011). In South America, categories II and IV are the most outstanding ones present in all countries. The lowest category found in the South American PAS is the Ib being present only in Argentina and Chile (Table 5).

Less restrictive areas are less common, even in countries where there are large percentages of protected territory, such as Venezuela. The establishment of PA

Table 4. Quantity, average size and index of implementation and effectiveness of the protected areas of the South American countries.

\begin{tabular}{|c|c|c|c|c|c|}
\hline Country & $\begin{array}{c}\text { Protected } \\
\text { Areas }\end{array}$ & $\begin{array}{l}\text { Average size of } \\
\text { protected areas } \\
\qquad\left(\mathrm{km}^{2}\right)\end{array}$ & $\begin{array}{c}\text { High degree of } \\
\text { implementation } \\
\text { and effectiveness } \\
(\%)\end{array}$ & $\begin{array}{l}\text { Medium degree of } \\
\text { implement-tation } \\
\text { and effectiveness } \\
(\%)\end{array}$ & $\begin{array}{c}\text { Low degree of } \\
\text { implementation } \\
\text { and effectiveness } \\
(\%)\end{array}$ \\
\hline Argentina & 436 & 493.46 & 39 & 61 & 00 \\
\hline Bolivia & 167 & $1,804.17$ & 32 & 68 & 00 \\
\hline Brazil & 1966 & 743.09 & 11 & 59 & 30 \\
\hline Chile & 187 & $1,483.62$ & -- & -- & -- \\
\hline Colombia & 621 & 224.09 & 22 & 69 & 9 \\
\hline Ecuador & 74 & 983.33 & 17 & 69 & 14 \\
\hline Guyana & 3 & $3,417.33$ & -- & -- & -- \\
\hline $\begin{array}{l}\text { French } \\
\text { Guyana }\end{array}$ & 29 & $1,651.03$ & -- & -- & -- \\
\hline Paraguay & 94 & 887.00 & 00 & 18 & 82 \\
\hline Peru & 152 & $1,574.94$ & 31 & 31 & 38 \\
\hline Suriname & 16 & $1,228.63$ & -- & -- & -- \\
\hline Uruguay & 15 & 177.93 & -- & -- & -- \\
\hline Venezuela & 400 & 976.15 & 25 & 50 & 25 \\
\hline
\end{tabular}

Source: Elbres (2011); TCU (2015). Note: Chile, Guyana, French Guyana, Suriname and Uruguay were not evaluated by the TCU - Federal Audit Court (TCU 2015).

Table 5. IUCN categories present in the Protected Areas Systems of the South American countries.

\begin{tabular}{|c|c|c|c|c|c|c|c|}
\hline & $\mathbf{I}-\mathbf{a}$ & $\mathbf{I}-\mathbf{b}$ & II & III & IV & V & VI \\
\hline Argentina & $\mathrm{X}$ & $\mathrm{x}$ & $\mathrm{x}$ & $\mathrm{X}$ & $\mathrm{x}$ & $\mathrm{x}$ & $\mathrm{X}$ \\
\hline Bolivia & $\mathrm{x}$ & & $\mathrm{X}$ & $\mathrm{x}$ & $\mathrm{x}$ & & $\mathrm{X}$ \\
\hline Brazil & $\mathrm{x}$ & & $\mathrm{X}$ & $\mathrm{x}$ & $\mathrm{x}$ & $\mathrm{x}$ & $\mathrm{x}$ \\
\hline Chile & $\mathrm{x}$ & $\mathrm{x}$ & $\mathrm{x}$ & $\mathrm{X}$ & $\mathrm{x}$ & $\mathrm{x}$ & $\mathrm{X}$ \\
\hline Colombia & $\mathrm{X}$ & & $\mathrm{x}$ & $\mathrm{x}$ & $\mathrm{x}$ & $\mathrm{x}$ & $\mathrm{X}$ \\
\hline Ecuador & $\mathrm{x}$ & & $\mathrm{X}$ & $\mathrm{X}$ & $\mathrm{x}$ & & $\mathrm{X}$ \\
\hline Guyana & & & $\mathrm{x}$ & & $\mathrm{x}$ & & $\mathrm{x}$ \\
\hline Paraguay & $\mathrm{X}$ & & $\mathrm{X}$ & $\mathrm{x}$ & $\mathrm{x}$ & $\mathrm{x}$ & $\mathrm{X}$ \\
\hline Peru & & & $\mathrm{X}$ & $\mathrm{x}$ & $\mathrm{x}$ & $\mathrm{x}$ & $\mathrm{x}$ \\
\hline Uruguay & $\mathrm{x}$ & & $\mathrm{X}$ & $\mathrm{x}$ & $\mathrm{x}$ & $\mathrm{x}$ & \\
\hline Venezuela & & & $\mathrm{x}$ & $\mathrm{X}$ & $\mathrm{x}$ & $\mathrm{x}$ & \\
\hline
\end{tabular}

Note: Ia- Strict natural reserve / Ib - Wildlife area / II- National park / III- Natural monument / IV- Area of management of species and habitats / V- Protected landscape / VI- Protected area for natural resources management. 
does not consistently respected the criteria for limiting human access (Dudley, 2008). In Brazil, for example, the category Area of Relevant Ecological Interest is classified as category IV of the IUCN, but in practice its use is less strict than that considered for categories I to IV. In some cases, PA denominated "National Parks" are managed according to criteria defined for category $\mathrm{V}$. It is common that the management of the areas, even categorized according to the IUCN, is determined by local characteristics (Jenkins \& Joppa, 2009; Meneguel \& Etchebehere, 2011).

There is a need to seriously consider land use in PA planning (Martinuzzi et al., 2015). Prioritizing areas of direct use of resources often allows diverse types of uses, such as wood exploitation, hunting, fishing or extractive activities, which without effective management interrupt the process of biodiversity conservation and generate conflicts between demands, where the lifestyle is based on these activities (Martin et al., 2016). In order to increase the effectiveness of the systems, appropriate and more comprehensive mechanisms must be found to guarantee more funding and prioritize the maintenance of the PA. In PA under greater threat, when financial resources are well targeted, biodiversity loss can be slowed down (Geldmann et al., 2015).

There is an increase in protected areas in the world, there will be more protected areas in the next 20 years than there was in the previous 20 years (Mcdonald \& Boucher, 2011). However, there is a clear tendency to create multiple use areas, which has also been verified in South America. Multi-use categories have greater flexibility in the use restrictions of their various resources, which can become a problem if they are not properly managed and do not respect the conservation objectives.

\section{CONCLUSION}

The establishment of a specific PA management system is an important commitment of the countries in order to manage the use of natural resources. PAS are efficient mechanisms to centralize actions, keeping rules appropriate to each area. Nevertheless, the effectiveness of the areas must be considered, ensuring adequate political and financial support for their management.

Systems with high number of categories cause confusion about their definitions and objectives, making it difficult to popularize these areas. It should also be considered that small and isolated areas do not fulfill the function of conserving biodiversity. Yet the large areas with low effectiveness and management rate neither do it. Therefore, although the South American protected area has increased in recent years, it has been observed that, there is only effective protection when areas have appropriated size and management.

Regarding the alignment of South American systems with the IUCN proposed System of Categories of Management of Protected Areas, it has been realized that countries are creating less restrictive areas and allowing greater direct human use. Countries with high percentage of protected territory, mostly, privilege such areas giving a false illusion of protection.

Thus, it is concluded that, in the management of protected areas, uniform actions are required, following well defined management criteria, in order to allow a global network of biodiversity protection.

\section{ACKNOWLEDGEMENTS}

Special thanks to the members of GAP (Grupo de Pesquisa em Planejamento e Gestão de Áreas Protegidas), GBV (Grupo Brasil Verde) and IF SUDESTE MG.

\section{SUBMISSION STATUS}

Received: 10 nov., 2017

Accepted: 22 dec., 2017

\section{CORRESPONDENCE TO}

\section{Geraldo Majela Salvio}

Rua Monsenhor José Augusto, 204, Bairro São José, CEP 36205-018, Barbacena, MG, Brasil e-mail: geraldo.majela@ifsudestemg.edu.br

\section{FINANCIAL SUPPORT}

Instituto Federal de Educação, Ciência e Tecnologia do Sudeste de Minas Gerais - IFSUDESTEMG (Grant/Award Number: 23223.000726/2018-61).

\section{REFERENCES}

Argentina. Secretaría de Ambiente y Desarrollo Sustentable. Administración de Parques Nacionales. Consejo Federal de Medio Ambiente. Resolución $n^{\circ} 70 / 03$, de 11 de septiembre 
de 2003. Estabelece Marco Estatutário del Sistema Federal de Áreas Protegidas. Boletín Oficial de la República Argentina, Buenos Aires (2003 sept.).

Armsworth PR, Cantú-Salazar L, Parnell M, Davies ZG, Stoneman R. Management costs for small protected areas and economies of scale in habitat conservation. Biological Conservation 2011; 144(1): 423-429. http:// dx.doi.org/10.1016/j.biocon.2010.09.026.

Bolívia. Ley $n^{\circ}$ 1.333, de 27 de abril de 1992. Ley del Medio Ambiente. Gaceta Oficial de Bolivia, Bolívia (1992 jun.).

Brasil. Lei $n^{\circ}$ 9. 985, de 18 de julio de 2000. Institui o Sistema Nacional de Unidades de Conservação (SNUC) e dá outras providências. Diário Oficial da República Federativa do Brasil, Brasília, DF (2000 jul.).

Brooks TM, Bakarr MI, Boucher T, da Fonseca GAB, Hilton-Taylor C, Hoekstra JM et al. Coverage provided by the global Protected-Area System: is it enough? Bioscience 2004; 54(12): 1081-1091. http://dx.doi.org/10.1641/00063568(2004)054[1081:CPBTGP]2.0.CO;2.

Bruner AG, Gullison RE, Rice RE, da Fonseca GAB. Effectiveness of Parks in protecting tropical biodiversity. Science 2001; 291(5501): 125-128. http://dx.doi.org/10.1126/ science.291.5501.125. PMid:11141563.

Butchart SHM, Walpole M, Collen B, van Strien A, Scharlemann JPW, Almond REA et al. Global biodiversity: indicators of recent declines. Science 2010; 328(5982): 1164-1168. http://dx.doi.org/10.1126/science.1187512. PMid:20430971.

Chape S, Harrison J, Spalding M, Lysenko I. Measuring the extent and effectiveness of Protected Areas as an indicator for meeting global biodiversity targets. Biological Sciences 2005; 360(1454): 443-455. http://dx.doi.org/10.1098/ rstb.2004.1592. PMid:15814356.

Chile. Ministerio de Agricultura. Ley $n^{\circ}$. 18.362, 27 de diciembre de 1984. Crea um Sistema Nacional de Áreas Silvestres Protegidas del Estado. Diario Oficial de la República de Chile, Santiago (1984 nov.).

Colombia. Ministerio de Ambiente, Vivienda y Desarrollo Territorial. Decreto $n^{\circ}$. 2.372, de 01 de julio de 2010. Reglamenta el Sistema Nacional de Áreas Protegidas, las categorías de manejo que lo conforman y se dictan otras disposiciones. Diário Oficial do Município de Colômbia, Bogotá (2010 jul.).

Davis M, Naumann S, McFarland K, Graf A, Evans D. Literature Review: the ecological effectiveness of the Natura 2000 network. 1st ed. Paris: European Topic Centre on Biological Diversity; 2014.

Don Carlos AW, Teel TL, Manfredo MJ, Mathur VB. Building capacity to enhance Protected Area management effectiveness: a current needs assessment for the Asian Context. The George Wright Forum 2013; 30(2): 154-162.

Dourojeanni MJ, Pádua MTJ. Biodiversidade: a hora decisiva. 1st ed. Curitiba: Universidade Federal do Paraná; 2001.
Dourojeanni MJ. Sistemas de áreas protegidas en América Latina: Teoría y práctica. Exégesis 2010; 2(3): 67-76.

Dudley N. Guidelines for applying Protected Area management categories. Gland: IUCN; 2008. http://dx.doi.org/10.2305/ IUCN.CH.2008.PAPS.2.en.

Ecuador. Estrategia preliminar para la Conservación de las Áreas Silvestres Sobresalientes del Ecuador. Quito: Servicio Forestal del Ecuador; 1976.

Eken G, Bennun L, Brooks TM, Darwall W, Fishpool LDC, Foster $\mathrm{M}$ et al. Key biodiversity areas as site conservation targets. Bioscience 2004; 54(12): 1110-1118. http://dx.doi. org/10.1641/0006-3568(2004)054[1110:KBAASC]2.0.CO;2.

Elbres J. Las áreas protegidas de América Latina: Situación actual y perspectivas para el futuro. Quito: UICN; 2011.

Fouda M, Grainger J, Salama W, El Din SB, Paleczny $\mathrm{D}$, Zalat $\mathrm{S}$ et al. Management effectiveness evaluation of Egypt's Protected Area System. Cairo: Ministry of State for Environmental Affairs; 2006.

Gay C. Sobre las causas de la disminución de lós montes de la Provincia de Coquimbo. In: Squeo FA, Arancio G, Gutiérrez JR, editor. Libro rojo de la flora nativa y de los sitios prioritarios para sua conservación: Región de Coquimbo. La Serena: Universidad de La Serena; 2001.

Geldmann J, Coad L, Barnes M, Craigie ID, Hockings M, Knights $\mathrm{K}$ et al. Changes in protected area management effectiveness over time: a global analysis. Biological Conservation 2015; 191: 692-699. http://dx.doi.org/10.1016/j. biocon.2015.08.029.

Guyana. Act $n^{\circ} 14$ of 2011. Protected Areas Act 2011. The Official Gazette. Georgetown (2011 july).

Humbley C, Canney SM. Conservation. Cambridge: Cambridge University Press; 2013.

International Union for Conservation of Nature - IUCN. United Nations List of National Parks and Protected Areas. Cambridge: IUCN Publications; 1985.

International Union for Conservation of Nature - IUCN. United Nations List of Protected Areas. Cambridge: IUCN Publications, 1998.

Irving MA, Matos K. Gestão de parques nacionais no Brasil: projetando desafios para a implementação do Plano Nacional Estratégico de Áreas Protegidas. Floresta e Ambiente 2006; 13(2): 89-96.

Jenkins CN, Joppa L. Expansion of the global terrestrial Protected Area System. Biological Conservation 2009; 142(10): 2166-2174. http://dx.doi.org/10.1016/j.biocon.2009.04.016.

Joppa LN, Loarie S, Pimm S. On the protection of "Protected Areas". Proceedings of the National Academy of Sciences of the United States of America 2008; 105(18): 6673-6678. http://dx.doi.org/10.1073/pnas.0802471105. PMid:18451028.

Jorquera-Jaramillo C, Alonso Veja JM, Aburto J, MartínezTillería K, León MF, Pérez MA et al. Conservación de la 
Biodiversidad en Chile: nuevos desafíos y oportunidades em ecosistemas terrestres y marinos costeros. Revista Chilena de Historia Natural 2012; 85: 267-280. http:// dx.doi.org/10.4067/S0716-078X2012000300002.

Juffe-Bignoli D, Burgess ND, Bingham H, Belle EMS, de Lima MG, Deguignet M et al. Protected Planet Report 2014. Cambridge: UNEP-WCMC; 2014.

Kharouba HM, Kerr JT. Just passing through: Global change and the conservation of biodiversity in protected areas. Biological Conservation 2010; 143(5): 1094-1101. http://dx.doi.org/10.1016/j.biocon.2010.02.002.

Leroux SJ, Krawchuk MA, Schmiegelow F, Cumming SG, Lisgo K, Anderson LG et al. Global protected areas and IUCN designations: do the categories match the conditions? Biological Conservation 2010; 143(3): 609-616. http://dx.doi.org/10.1016/j.biocon.2009.11.018.

Lushaj B, Malsia-Lushaj V, Lushak A, Lushaj A. Recognition, dedication and management of the Protected Areas, as and understanding and enhancing of the ecotourism are great opportunities given through education, a request of time in Albania. Online International Interdisciplinary Research Journal 2016; 5: 2249-9598.

Margules CR, Pressey RL. Systematic conservation planning. Nature 2000; 405(6783): 243-253. http://dx.doi. org/10.1038/35012251. PMid:10821285.

Martin A, Coolsaet B, Corbera E, Dawson NM, Fraser JA, Lehmann I et al. Justice and conservation: the need to incorporate recognition. Biological Conservation 2016; 197: 254-261. http://dx.doi.org/10.1016/j.biocon.2016.03.021.

Martinuzzi S, Radeloff VC, Joppa LN, Hamilton CM, Helmers DP, Plantinga AJ et al. Scenarios of future land use change around United States' protected areas. Biological Conservation 2015; 184: 446-455. http://dx.doi. org/10.1016/j.biocon.2015.02.015.

McDonald RI, Boucher TM. Global development and the future of the protected area strategy. Biological Conservation 2011; 144(1): 383-392. http://dx.doi.org/10.1016/j. biocon.2010.09.016.

Meneguel CA, Etchebehere MLC. Parques Nacionais no Brasil e a prática do turismo sustentável. Revista Hospitalidade 2011; 8(1): 78-94.

Orlikowska EH, Roberge JM, Blicharska M, Mikusiński G. Gaps in ecological research on the world's largest internationally coordinated network of protected areas: a review of Natura 2000. Biological Conservation 2016; 200 : 216-227. http://dx.doi.org/10.1016/j.biocon.2016.06.015.

Paraguay. Congreso de la Nación Paraguaya. Ley $n^{\circ}$ 352/94 de Áreas Silvestres Protegidas. Gaceta Oficial de la República del Paraguay. Asunción (1994).

Peru. Ley $N^{\circ} 26834$ de 17 julio de 1997. Ley de Areas Naturales Protegidas. Diário Oficial El Peruano. Lima (1997 jul.).
Pimm SL, Ayres M, Balmford A, Branch G, Brandon $\mathrm{K}$, Brooks T et al. Can we defy nature's end? Science 2001; 293(5538): 2207-2208. http://dx.doi.org/10.1126/ science.1061626. PMid:11567124.

Prates APL, Irving MA. Conservação da biodiversidade e políticas públicas para as áreas protegidas no Brasil: desafios e tendências da origem da CDB às Metas de Aichi. Revista Brasileira de Politicas Publicas 2015; 5: 28-57.

Rodrigues ASL, Akcakaya HR, Andelman SJ, Bakarr MI, Boitani L, Brooks TM et al. Global Gap Analysis: priority regions for expanding the global Protected-Area network. Bioscience 2004b; 54(12): 1092-1097. http:// dx.doi.org/10.1641/0006-3568(2004)054[1092:GGAP $\mathrm{RF}] 2.0 . \mathrm{CO} ; 2$.

Rodrigues ASL, Andelman SJ, Bakarr MI, Boitani L, Brooks TM, Cowling RM et al. Effectiveness of the Global Protected Area network in representing species diversity. Nature 2004a; 428(6983): 640-643. http://dx.doi. org/10.1038/nature02422. PMid:15071592.

Santos CF, Krawiec VAM. A situação ambiental e a administração das Unidades de Conservação em Campo Grande-MS, na visão de seus gestores. Floresta e Ambiente 2011; 18(3): 334-342. http://dx.doi.org/10.4322/ floram.2011.053.

Scharlemann JPW, Kapos V, Campbell A, Lysenko I, Burgess ND, Hansen MC et al. Securing tropical forest carbon: the contribution of protected areas to REDD. Oryx 2010; 44(03): 352-357. http://dx.doi.org/10.1017/ S0030605310000542.

Schodelbauerova I, Roberts DL, Kindlmann P. Size of protected areas is the main determinant of species diversity in orchids. Biological Conservation 2009; 142(10): 23292334. http://dx.doi.org/10.1016/j.biocon.2009.05.015.

Tribunal de Contas da União - TCU. Relatório da Auditoria Coordenada em Áreas Protegidas da América Latina. Brasília: TCU; 2015.

Tuvi EL, Vellak A, Reier Ü, Szava-Kovats R, Pärtel M. Establishment of protected areas in different ecoregions, ecosystems, and diversity hotspots under successive political systems. Biological Conservation 2011; 144(5): 1726-1732. http://dx.doi.org/10.1016/j.biocon.2011.03.008.

Uruguay. Ley $n^{\circ} 17234$ de 22, de febrero de 2000. Crea o Sistema Nacional de Areas Protegidas do Uruguay. Diario Oficial de la República del Uruguay. Montevideo (2000).

Venezuela. Lei $n^{\circ} 3.238$ de 11, de agosto de 1983. Decreta la Siguiente, Ley Organica para la Ordenacion del Territorio. Gaceta Oficial de la Republica de Venezuela. Caracas (1983).

Watson JEM, Dudley N, Segan DB, Hockings M. The performance and potential of protected areas. Nature 2014; 515(7525): 67-73. http://dx.doi.org/10.1038/nature13947. PMid:25373676.

Willis KJ, Jeffers ES, Tovar C, Long PR, Caithness N, Smit MGD et al. Determining the ecological value of landscapes 
beyond protected areas. Biological Conservation 2012; 147(1):3-12. http://dx.doi.org/10.1016/j.biocon.2011.11.001.

Zhu L, Zhan X, Meng T, Zhang S, Wei F. Landscape features influence gene flow as measured by cost-distance and genetic analyses: a case study for giant pandas in the Daxiangling and Xiaoxiangling Mountains. BMC Genetics
2010; 11(1): 72. http://dx.doi.org/10.1186/1471-2156-1172. PMid:20653932.

Zimmerer KS, Galt RE, Buck MV. Globalization and multispatial trends in the coverage of protected-area conservation (1980-2000). Ambio 2004; 33(8): 520-529. http://dx.doi. org/10.1579/0044-7447-33.8.520. PMid:15666684. 